\title{
Toughness analysis of pineapple leaves fiber composite as alternative material for SNI helmet
}

\author{
Bagus Tri Mulyo ${ }^{1}$, Heri Yudiono ${ }^{2 *}$ \\ ${ }^{1}$ Mechanical Engineering Education, Faculty of Engineering, Universitas Negeri Semarang. \\ ${ }^{2}$ Mechanical Engineering, Faculty of Engineering, Universitas Negeri Semarang, \\ 50229, Semarang, Jawa Tengah, Indonesia. \\ *Email: heri_yudiono@mail.unnes.ac.id
}

Phone: +628164251208

\begin{abstract}
Along with the times utilization of natural fibers composite materials has been developed. The purpose of this research was to know the impact strength of pineapple leaves fiber composites before applied to basic material for Indonesia National Standard (SNI) helmet. Design of this research was true experimental with posttest-only control design, in this research there were two group, namely experimental group (fiber composite) and control group (SNI helmet). Result of this research showed there was improvement about composite strength with addition fibers volume. The value of absorbed energy and the highest impact strength is found in $10 \%$ of fiber volume equals 0.5375 Joules and $0.01657 / \mathrm{mm}^{2}$, far above the SNI helmet which only amounted to 0.3125 Joules and $0.00972 \mathrm{~J} / \mathrm{mm}^{2}$. For the highest density value is found in $13 \%$ of fiber volume equals $1.4525 \mathrm{~g} / \mathrm{cm}^{3}$. It can be concluded that pineapple leaves fiber composites can be used as an alternative material for making SNI helmet.
\end{abstract}

Keywords: Composites; pineapple leaf; impact strength; SNI helmet.

\section{INTRODUCTION}

Along with the times utilization of composite materials especially using natural fiber has been developed, start from simple tools to the industrial sector. The use of natural fiber composite materials which are easily formed, have good strenght, environmentally friendly and can be recycled again is the demands of the current technology. Composites, consist of two or more separate materials combined in a macroscopic structural unit and generate a new materials, that is more useful and has different properties with its constituent materials [1].

Natural fiber basically classified as animal, cellulose and mineral fiber as shown in Figure 1. The use of natural fibers as reinforcement for composite materials replaces the role of synthetic fibers is one wise step to increasing the economic value of natural fibers given the limited natural resources that cannot be renewed. The potential of natural fibers is supported by several advantages of organic fiber, among others: low density, environmentally friendly, biodegradable, abundant availability, high toughness, relatively 
easy preparation process, relatively cheap raw material prices, and reduced manufacturing energy consumption [2].

Composites with cellulose fiberreinforced, their mechanical properties will increase as well as the increase in fiber volume, the improved mechanical properties are tensile strength, bending, and impact strength [3]. Furthermore, cellulose fiber is easy in handling and process for experimental and installation purpose compare to animal and mineral fiber [4]. A lot of different cellulose fibers such as jute, flax, kenaf, hemp, coir, sisal, and PALF are being studiedaround the world [5].

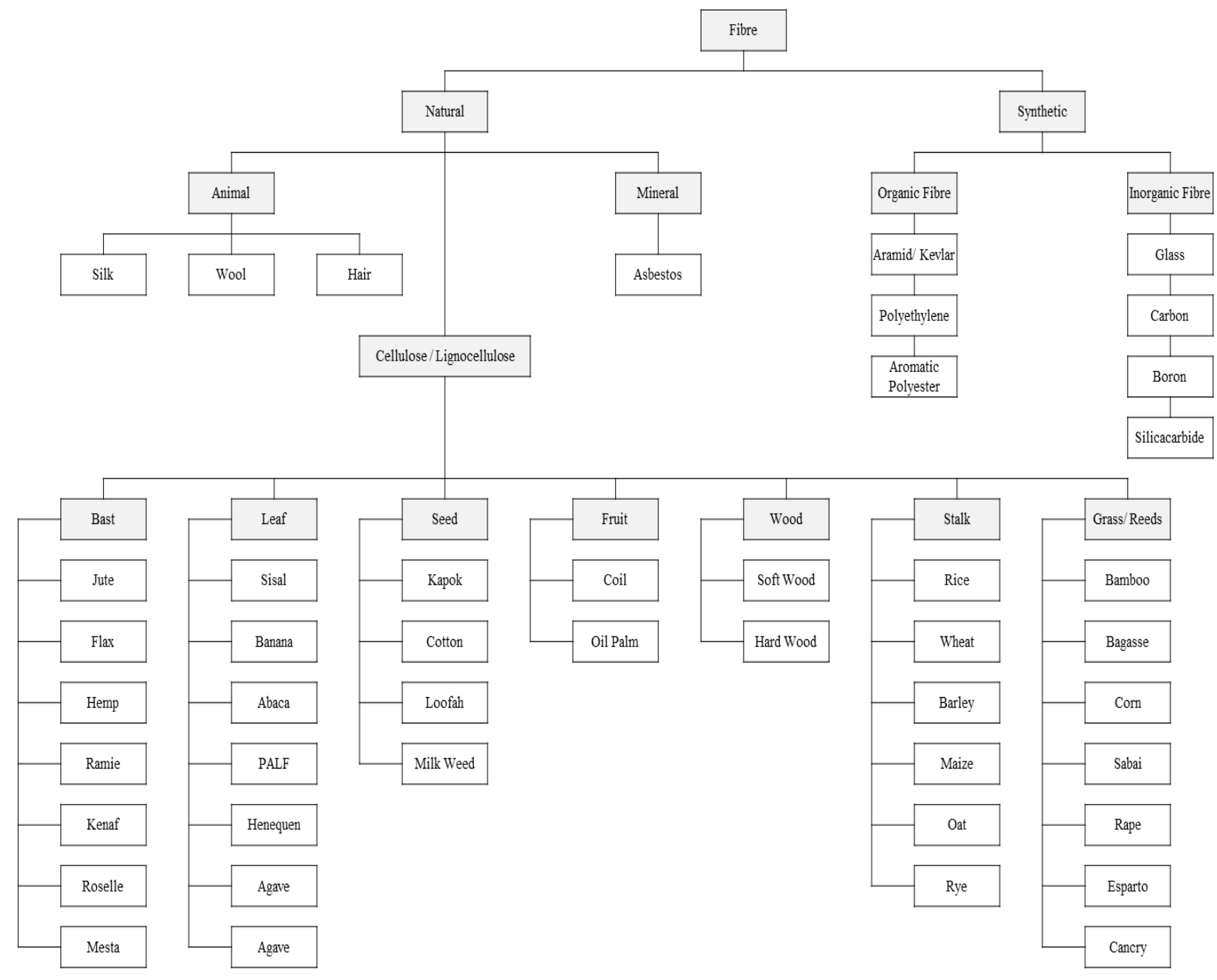

Figure 1. Classification of natural fiber [6].

Pineapple plants are plants that are found throughout Indonesia, so the production of pineapple is very abundant. Until now, the use of pineapple leaves fiber is only used for household crafts in the form of webbing and is still rarely used for commodities in the industrial world. Pineapple Leaves Fiber (PALF) consist of cellulose around 70-80\% provides high spesific modulus and strength, this causes pineapple leaves to be used as an 
efficient reinforcement of natural fiber composites [7]. The selling value of pineapple leaves can almost be said to have no selling value at all, because it is more often thrown away than used. So it is necessary to do other innovations to utilize pineapple leaf waste which is very abundant, one of them is for new reinforcement materials in natural fiber composites that are cheap and environmentally friendly so that they can be useful and have a high selling value.

Helmet is a part of motorcycle equipment in the form of a head protector that serves to protect the wearer's head in the event of a collision [8]. In addition, the helmet also serves to protect the wearer from dust, sand, and other small objects that are dangerous when driving. Therefore, the Law of the Republic of Indonesia Number 14 of 1992 Article 23 requires motorcycle riders to wear helmets as head protectors. Given the function of the helmet, the material for the helmet maker must be able to protect the head from collisions in the event of an accident. Law of the Republic of Indonesia Number 22 of 2009 Article 57 determined that the helmet used to drive must meet Indonesian National Standard (SNI).

\section{METHODS AND MATERIALS}

\section{Pineapple Leaves Fiber}

The process of taking leaves fiber can be done in two ways, namely by hand (manual) or by decorticator equipment. The most common and practical way was manually, namely by water retting and scraping. The extraction of pineapple leaves fiber generally at the age of plants ranging from 1 to 1.5 years. Fibers that comes from young pineapple leaf generally not long and less strong, while fibers from old pineapple leaf will produced short, rough, and, brittle or fragile fibers. Therefore, to get strong, smooth, and soft fiber, it was necessary to choose pineapple leaf that were mature enough that growth was partly protected from sunlight [9].

\section{Polyester Matrix}

Polyester matrix were most widely used especially for lightweight construction applications. The advantage of polyester matrix compared to other matrix was the polyester matrix was harder, produces transparent material, strong, had good resistance to water, weather, and the influence of chemicals, also can be combined with all types of glass fibers, and the price is cheaper [10].
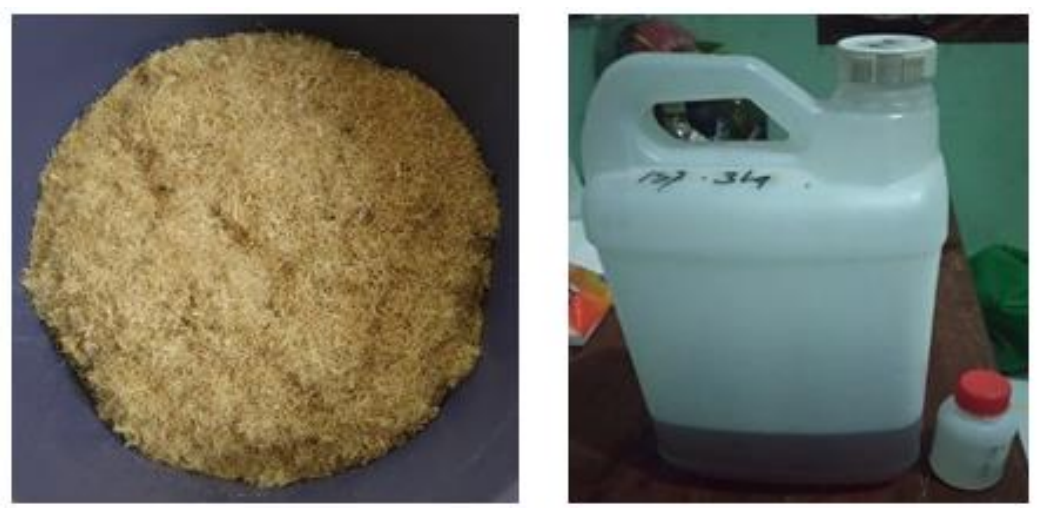

Figure 2. Pineapple leaves fiber and Polyester matrix. 


\section{Methods}

This research used an experimental method, with the design of true experimental design and posttest-only control design. Composite printing is done manually with the hand lay up method. There were two groups in this research, namely the experimental group and the control group. The experimental group was a group that had addition fibers volume. While the control group was SNI helmet specimen. Variation in the volume fraction of pineapple leaves fiber used were $3 \%, 5 \%, 8 \%, 10 \%$, and $13 \%$. To produce cleaner and stronger fiber, pineapple leaves fiber is given an alkaline treatment, which is soaked in $5 \% \mathrm{NaOH}$ solution for 2 hours.

The materials that used in this research were pineapple leaves fiber, polyester resin as matrix, catalyst, and margarine used as wax. The equipment used in this research were GOTECH impact testing machines, composite molds, grinding machines used for cutting and forming specimens, 40 mesh for composite filtering, digital scales for weighing fibers volume, and measuring cup for measuring resin with catalysts. The research process started from preparation stage, which was to cut the fibers into small pieces then filtered it using a mesh, also prepare polyester resin and catalyst. The next step was composite printing, which is coating the base of the mold with margarine then pouring a mixture of fibers, polyester resin and catalyst which was measured the volume first into the mold little by little until distributed, flatten so that there is no air trapped inside the mold, then press the mold until it touched the stopper to match the thickness of the workpiece to be made. The size of impact test specimens used was in accordance with ISO 179-1 standards [11].

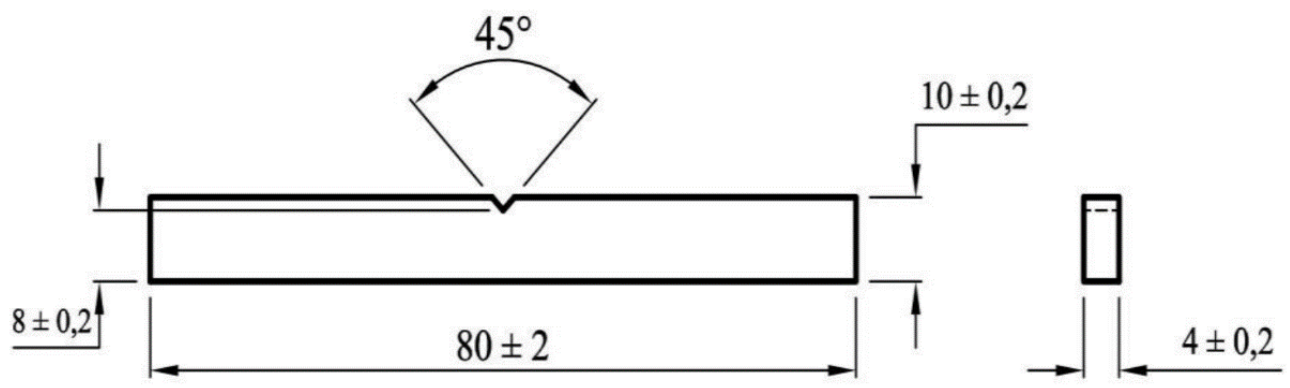

Figure 3. Dimension of ISO179-1 standard impact test specimens.

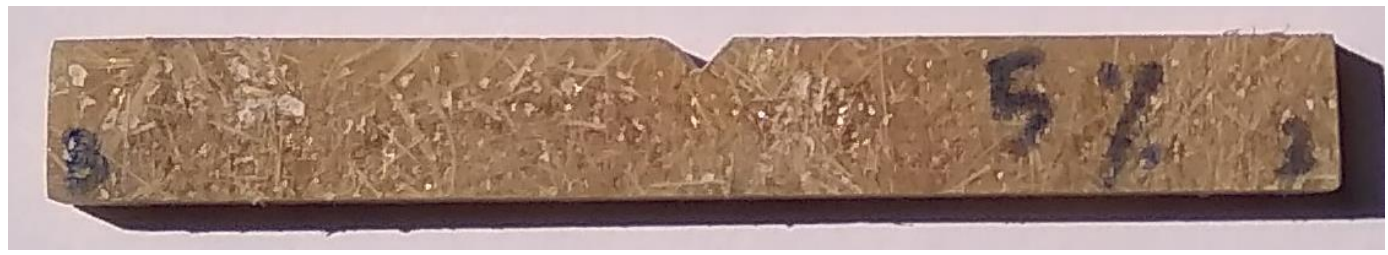

Figure 4. Composite specimen.

The research data was taken from each of the tested specimens and then analyzed. The data analysis technique used in this research was descriptive statistical. Data obtained from testing the impact of each specimens and then measured the average. Data is presented in graphical form. 


\section{RESULTS AND DISCUSSION}

The specimens in this research consisted of 24 test specimens and 12 reserve specimens used if the test specimen failed. Specimens consisted of six SNI helmet specimens that were used as controls (four test specimens and two as reserves), and each six specimens for composites with fibers volume fraction variations of $3 \%, 5 \%, 8 \%, 10 \%$, and $13 \%$ (four as test specimens and two as reserves). The type of impact testing used is charpy notched.

\section{Results}

The results of testing the impact of pineapple leaves fiber composite and polyester matrix obtained the value of impact absorption energy and impact strength. The results of composite impact testing can be seen in Figure 5 and Figure 6.

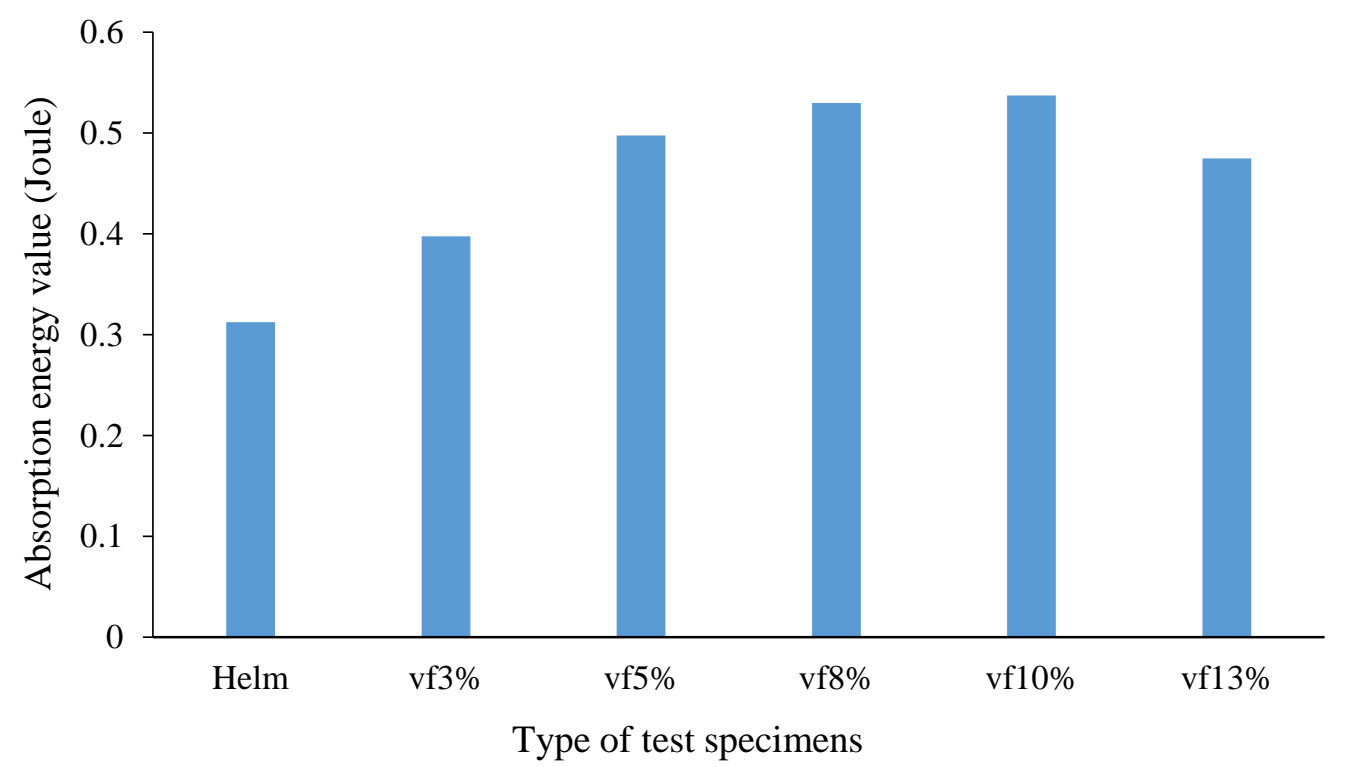

Figure 5. Average impact absorption energy of pineapple leaves fiber composite.

The results of impact testing showed that the pineapple leaves fiber composite had a higher average absorption energy value than SNI helmet specimen. Result of the highest impact absorption energy occurs in pineapple leaves fiber composite with volume fraction of $10 \%$ at 0.5375 Joule, while the lowest absorption energy value is a specimen of SNI helmet of 0.3125 Joule. 


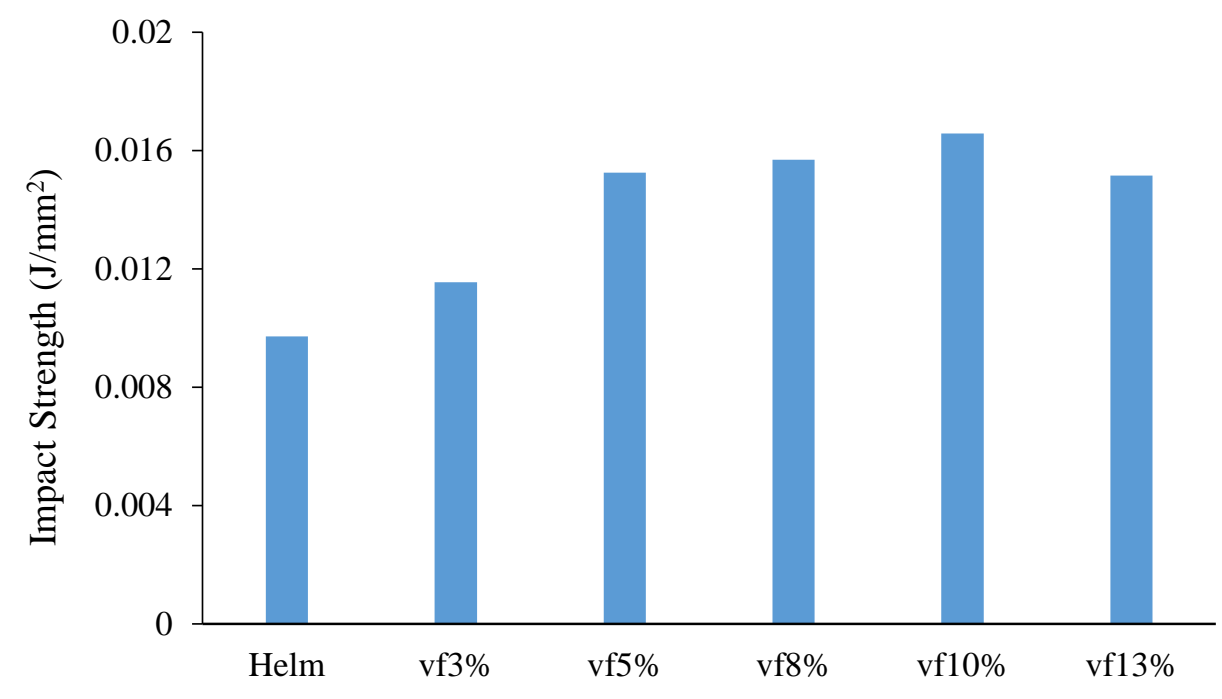

Type of test specimens

Figure 6. Average impact strength of pineapple leaves fiber composite.

The results of the impact strength value, pineapple leaves fiber composite-polyester had a higher average value than SNI helmet specimen. The highest value of impact strength was in the pineapple leaves fiber composite with $10 \%$ volume fraction of $0.01657 \mathrm{Joule} / \mathrm{mm}^{2}$, while SNI helmet specimen had a smallest impact strength value which was only 0.00972 Joule $/ \mathrm{mm}^{2}$. Furthermore, density testing is used to determine the density of a composite material. It can be seen in Figure 7.

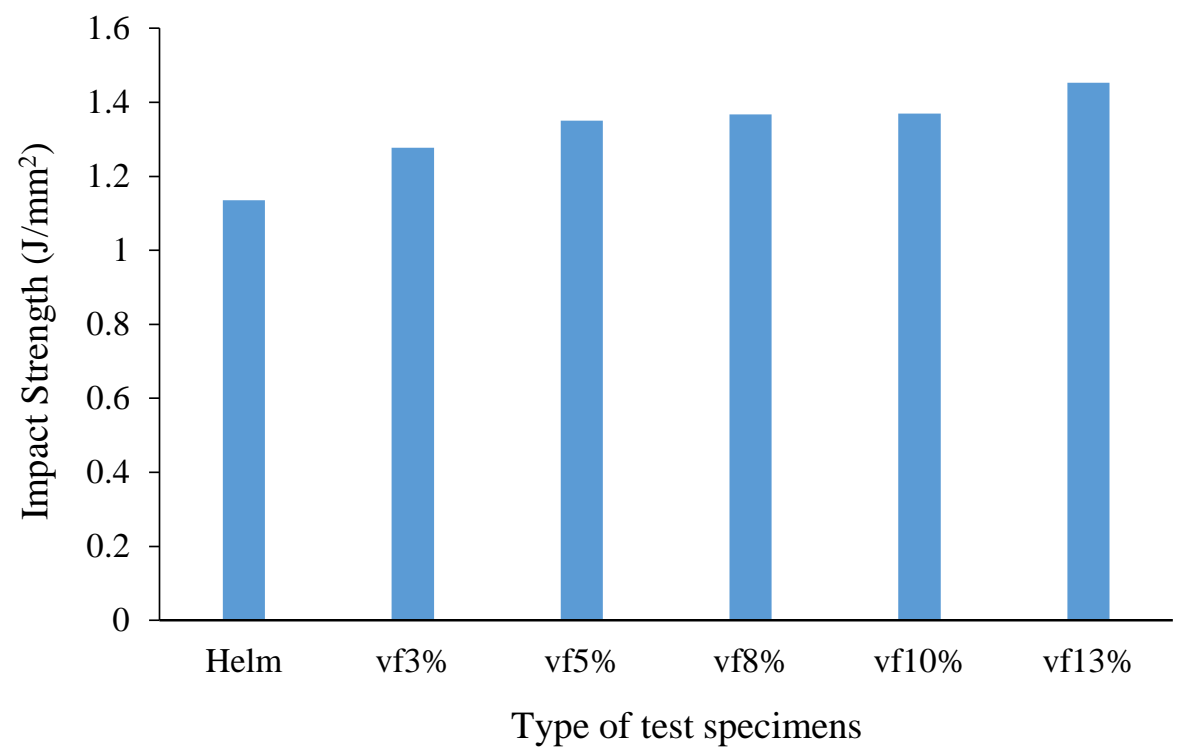

Figure 7. Average density of pineapple leaves fiber composite. 
The highest density results occur in pineapple leaves fiber composite with a volume fraction of $13 \%$ at $1.4525 \mathrm{gram} / \mathrm{cm}^{3}$, while the lowest density value was the specimen from SNI helmet of $1.135 \mathrm{gram} / \mathrm{cm}^{3}$. The results of macro photo fracture of pineapple leaves fiber composite after impact testing as follows:

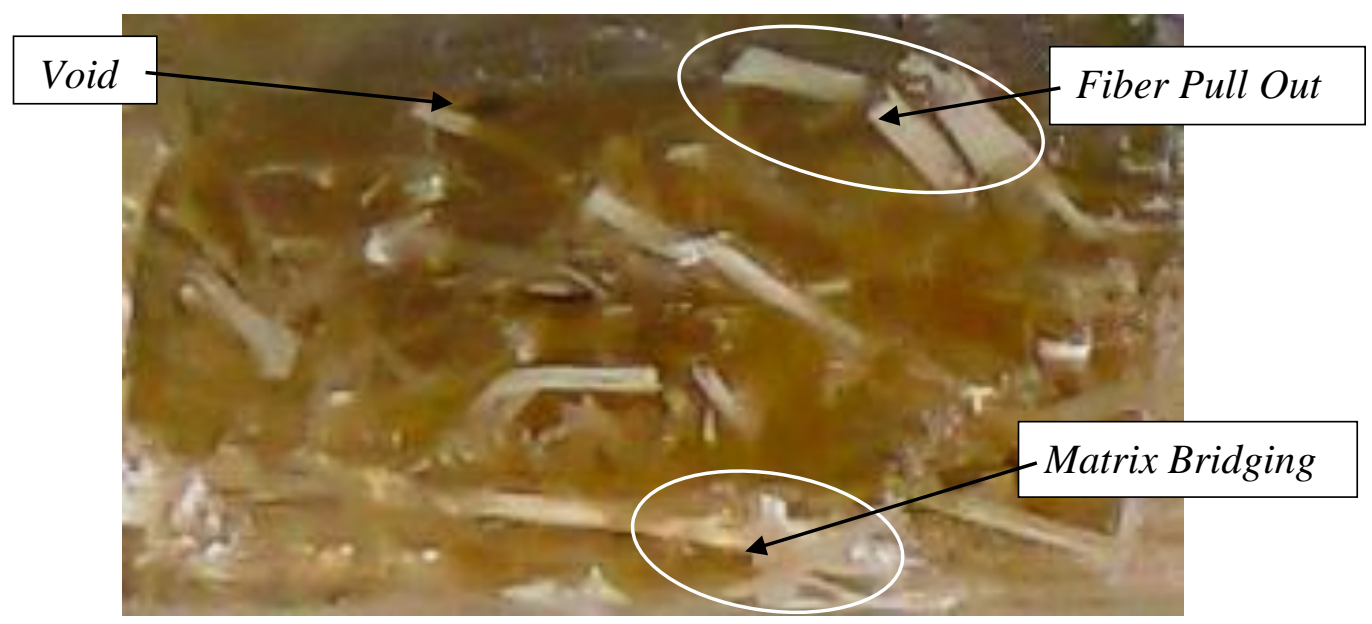

Figure 8. Fault of pineapple leaves fiber composite with 3\% volume fraction

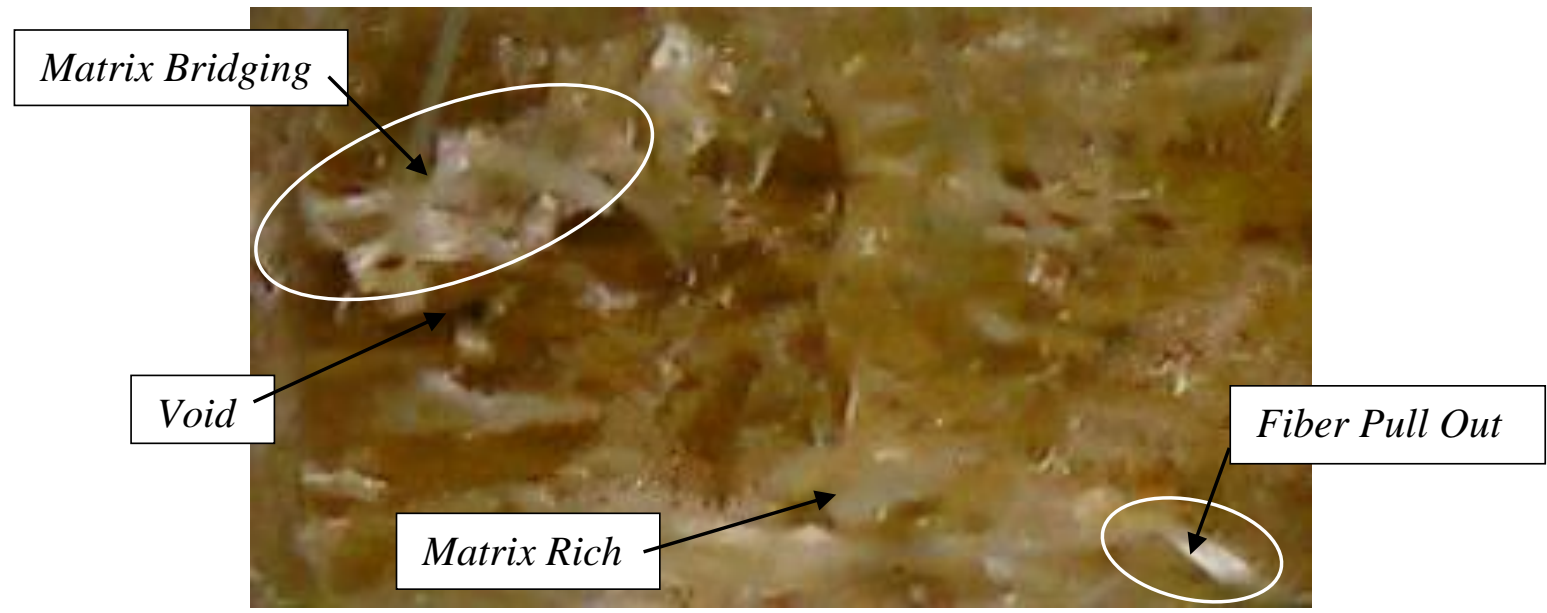

Figure 9. Fault of pineapple leaves fiber composite with 5\% volume fraction 


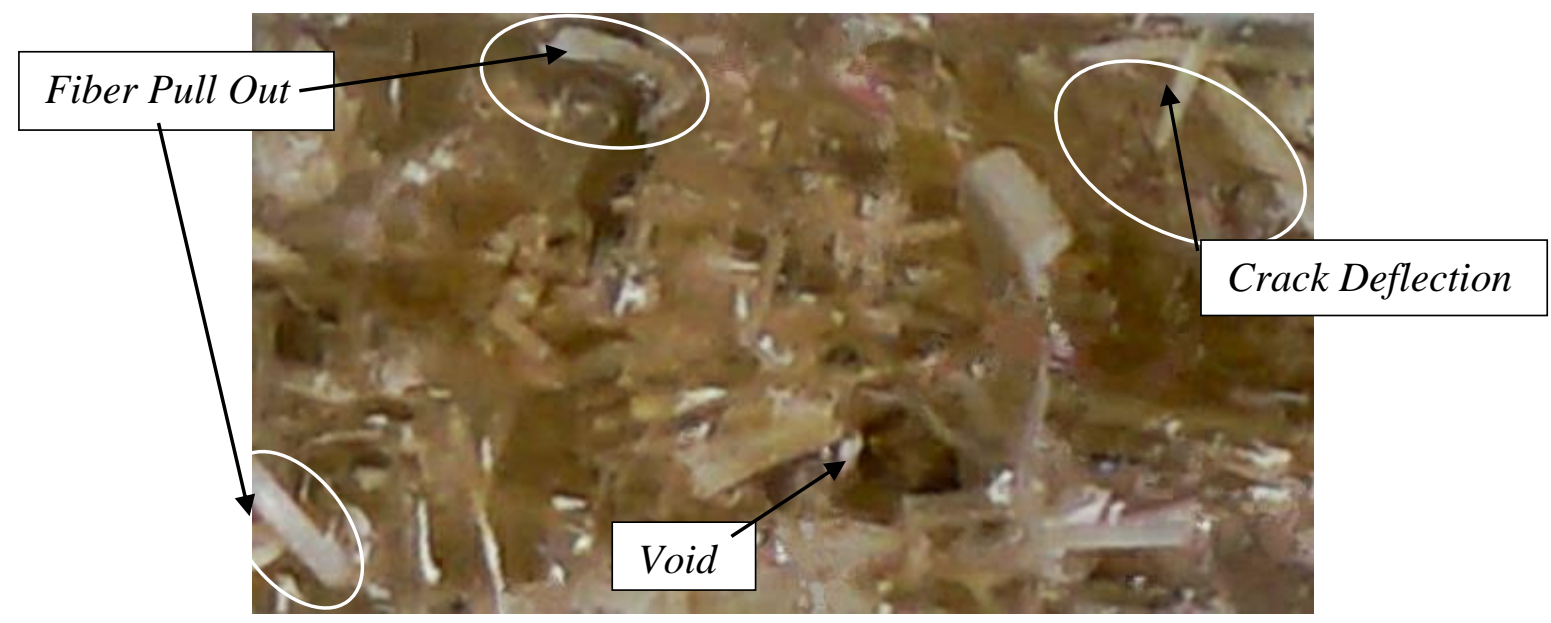

Figure 10. Fault of pineapple leaves fiber composite with $8 \%$ volume fraction

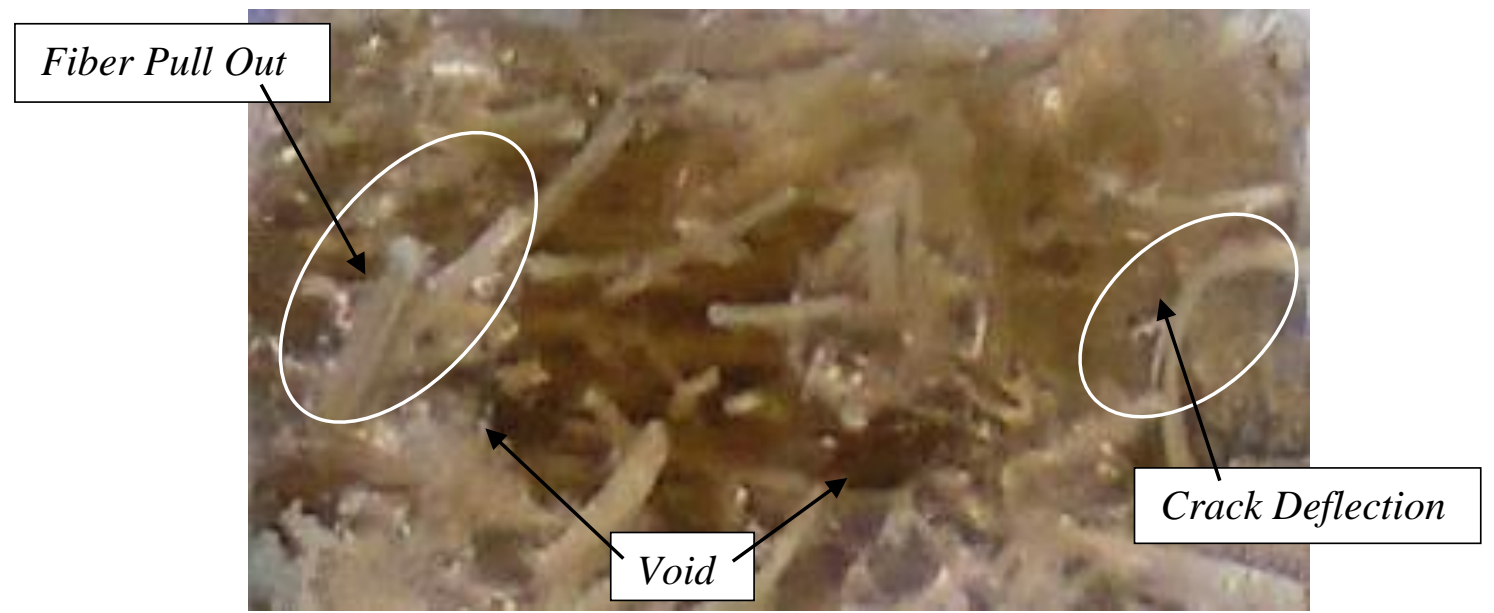

Figure 11. Fault of pineapple leaves fiber composite with $10 \%$ volume fraction

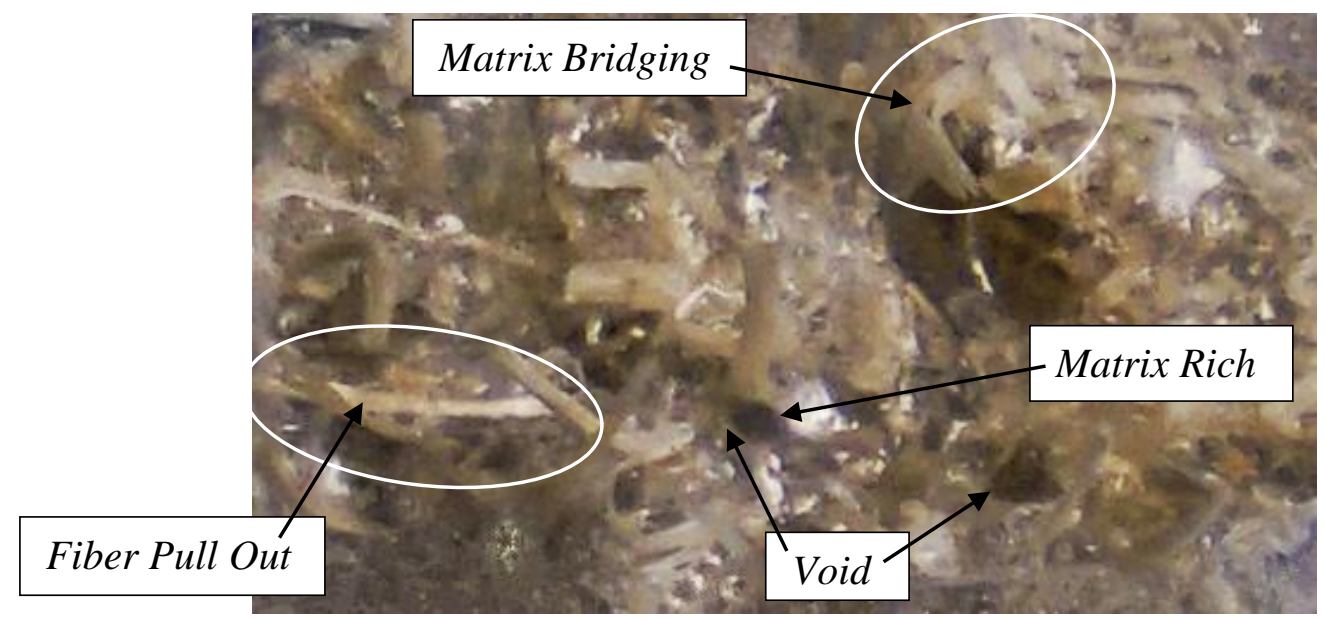

Figure 12. Fault of pineapple leaves fiber composite with $10 \%$ volume fraction 


\section{DISCUSSIONS}

Based on research results, the impact testing showed that the addition of the volume fraction of pineapple leaves fiber had an effect on increasing the average value of composite impact absorption energy, where the greater the fiber volume fraction, the greater the impact absorption energy of the composite will be increased. Addition of pineapple fiber volume fraction also affected the increase value of composite impact strength, where the greater the fiber volume fraction, the greater the impact strength value. This is consistent with previous research which stated that the addition of the fiber volume fraction in the composite had a positive effect which is strengthening tensile strength and impact strength [12].

Furthermore, the research result also showed that the matrix volume fraction factor used was the use of polyester resin matrix which was also influenced by the volume fraction of pineapple leaf fibers used. Glass-reinforced plastics must contain about $70 \%$ of the glass volume to achieve metal strength, this indicated that a good composite must have a large amount of reinforcing or fiber material or a large fiber volume fraction that significantly increases the mechanical strength of the composite and can competed with other materials [13]. The greater the volume fraction of the pineapple leaves fiber used, the less the volume fraction of the polyester matrix used in the manufacture of composites. If the less volume matrix fraction is used, then the impact strength of the composite will be decreased, but because it is given an addition of fiber volume fraction on the composite, it is able to coverage the deficiency caused by the reduction matrix volume fraction with the bonding requirement between fiber and matrixas well must be good, so it produced a good impact strength value. This is consistent with previous research which stated that fiber composites when given an impact load, the specimen will be increased of impact absorption energy and impact strength values in each addition fiber volume fraction [14].

Pineapple leaves fiber composite with $10 \%$ volume fractionshowed the most higher results among specimens with other test volume fraction variations, the impact absorption energy value of 0.5375 Joule and the highest impact strength value is also found on composite specimens with $10 \%$ fiber volume fraction of $0.01657 \mathrm{Joule} / \mathrm{mm}^{2}$. But there are certain limits on the value of absorption energy and impact strength will continue to increase. In this study the limit of the increase in absorption energy value and impact strength occurs in pineapple leaves fiber composites with $10 \%$ volume fraction, while in $13 \%$ volume fraction variation decreases the absorption energy and impact strength values produced,there is pineapple leaves fiber composites with $13 \%$ volume fraction only has an impact absorption energy value of 0.475 Joule and an impact strength value of $0.01515 \mathrm{Joule} / \mathrm{mm}^{2}$. This can happen because the larger the volume fraction of the pineapple leaves fiber causes the matrix be less and less, so that the bond between the matrix and the fiber will be weaker which can lead to the emergence of a lot of clumpsof pineapple leaves fiber and the fiber cannot spread well in the matrix. This is consistent with previous research which stated the decrease in impact strength when increasing the filler content was due to the interfacial interaction between the matrix and filler was weak [15]. These results indicate that differences in the volume fraction variation of pineapple leaves fiber greatly influence the value of the composite impact strength.

The pineapple leaves fiber composite is also stronger than plastic material where in testing the impact of SNI helmet samples, the impact strength is only $0.00972 \mathrm{Joule} / \mathrm{mm}^{2}$; whereas the pineapple leaves fiber composite has an optimum impact strength value of 
$0.01657 \mathrm{Joule} / \mathrm{mm}^{2}$ at a fiber volume fraction of $10 \%$. From these results showed that the pineapple leaves fiber composite can be used as a base for plastic replacement in the manufacture of SNI helmets. SNI helmets are generally made with plastic materials, namely polypropelene polymer without fiber reinforcement. Things that can causing high impact strength values in the $10 \%$ fiber volume fraction affected by several factors, namely the presence of fibers and matrix that are bonded together, the length of the fiber, and fiber treatment given. These factors can increase the strength of composite mechanics[16]. The addition of fiber in the manufacture of composites is very influential on composite performance. Because the load received by the material is not direct work at one point, but the load will be divided into several points and held back by the bond between fibers and matrix before experiencing fracture. Fiber orientation also affects the toughness of a composite material [17].

Based on research result, the increase in absorption energy and impact strength is also influenced by the $\mathrm{NaOH}$ treatment during the process of making fibers. According to previous research, $\mathrm{NaOH}$ solution was used to separate fibers from cellulose and lignin and remove impurities that adhere to the fibers, so it can increased the attachment of fibers and matrix which results in more unity and strength [18]. This is consistent with the opinion of other researchers who says that the reduced hemicellulose, lignin or pectin, the fiber hardness by the matrix will be better, so that the interface strength will increased, and will increase surface roughness which results in better mechanical interlocking [19].

The highest density value was obtained from the composite with a volume fraction of $13 \%$ at $1.4525 \mathrm{gram} / \mathrm{cm}^{3}$. The results of density testing showed that the addition of the volume fraction of pineapple leaves fiber could increase the density value of pineapple leaves fiber composite. This is consistent with previous research that increase the density value in composites due to the higher fiber volume fraction, the composite density also increases [20].

The results of macro photos of the composite fractures of pineapple leaves fiber composite, fractures that occur more due to fiber pull out, void and crack deflection. All broken specimens using fiber are all specimens experiencing voids and fiber pull out. The fault area is void because when making fiber composite with hand lay up process there is air trapped when the matrix mixing to the fiber arenot maximum, causing the formation of air cavity in the matrix. At the time of impact testing, pendulum load conditions is well received by fiber and matrix bonding, so that the fiber supports impact loads and fibers that experience direct impact in the form of fiber pull out. Fiber pull out occurs due to the lack of bond between the fiber and the matrix so that the fiber is separated from the matrix bond. Weak bond interface between fiber and polyester will result in fiber pull out[21].

\section{CONCLUSION}

Based on the research, observation, explanation and analysis, it can be concluded that the highest impact absorption energy occurs in pineapple leaves fiber composite with volume fraction of $10 \%$ at 0.5375 Joule and the highest impact strength value is also found on pineapple leaves fiber composite with volume fraction of $10 \%$ at $0.01657 \mathrm{Joule} / \mathrm{mm}^{2}$. The results of the macro photo test of composite specimens of pineapple leaves fiber composite have a different cross section shape but there is fiber pull out and voids on all variations of the fiber volume fraction. For the highest density value was obtained from pineapple leaves 
fiber composite with volume fraction of $13 \%$ at $1.4525 \mathrm{gram} / \mathrm{cm}^{3}$. Based on the research process, there are several things that need to be considered, including the process of making composites should be arranged evenly, so that no voids occur and additional variations of other materials are needed to strengthen the bond between fibers and matrix, so that the strength of the material can be increased.

\section{REFERENCES}

[1] Gibson. Principles of composite material mechanics. 4th ed. New York: McGrawHill, Inc; 1994.

[2] Chandramohan D, Bharanichandar J. Natural fiber reinforced polymer composites for automobile accessories. American Journal of Environmental Sciences. 2013;9(6):494-504.

[3] Stark NM, Rowlands RE. Effects of wood fiber characteristics on mechanical properties of wood/polypropylene composites. Wood and fiber science. 2003;35(2):167-174.

[4] Noryani M, Sapuan SM, Mastura MT. Multi-criteria decision-making tools for material selection of natural fiber composites: A review. Journal of Mechanical Engineering and Sciences. 2018;12(1):3330-53.

[5] Jahan A, Rahman M, Kabir H, Kabir MA, Ahmed F, Hossain MA, Gafur MA. Comparative study of physical and elastic properties of jute and glass fiberreinforced LDPE composites. International Journal of Scientific and TechnologyResearch. 2012;1;10:68-72.

[6] Al-Oqla FM, Sapuan SM, Anwer T, Jawaid M, Hoque ME. Natural fiber reinforced conductive polymer composites as functional materials: A review. Synthetic Metals. 2015;206:42-54.

[7] Panyasart K, Chaiyut N, Amornsakchai T, Santawitee O. Effect of surface treatment on the properties of pineapple leaf fibers reinforced polyamide 6 composites. Energy Procedia. 2014;56:406-413.

[8] SNI 1811. Helm pengendara kendaraan bermotor roda dua. Jakarta: BSN; 2007.

[9] Hidayat P. Teknologi pemanfaatan serat daun nanas sebagai alternatif bahan baku tekstil. Jurnal Teknoin. 2008;13(2):31-35.

[10] Ismail MF, Abdi C, Syarief A. Pemanfaatan limbah kapas puntung rokok menjadi material papan komposit bermatrik polyester. Jernih: Jurnal Tugas Akhir Mahasiswa Program Studi Teknik Lingkungan. 2017;1(1):1-8.

[11] International Organization for Standardization (ISO). Plastics-determination of charpy impact properties, Part 1: on-instrumented impact test. 2010;179-1.

[12] Fauzi F, Ghazalli Z, Siregar J. Effect of various kenaf fiber content on the mechanical properties of composites. Journal of Mechanical Engineering and Sciences. 2016;10:2226-33.

[13] Vlack Van Lawrence H. Ilmu dan teknologi bahan. $5^{\text {th }}$ edition. Jakarta: Erlangga; 1991.

[14] Lumintang RC, Soenoko R, Wahyudi S. Komposit hibrid polyester berpenguat serbuk batang dan serat sabut kelapa. Rekayasa Mesin.2011;2(2): 145-153. 
[15] Halim NA, Siregar JP, Mathivanan D, Bachtiar D, Ghazali Z, Rejab MRM, Tezara C. The performance of mengkuang leaf fiber reinforced low density polyethylene composites. Journal of Mechanical Engineering and Sciences. 2018;12(2):3645-55.

[16] Loh XH, Daud MM, Selamat MZ. Mechanical properties of kenaf/polypropylene composite: An investigation. Journal of Mechanical Engineering and Sciences. 2016;10(2):2098-2110.

[17] Yudiono H, Anis S, Masugino, Pramono. Kekuatan bending panel komposit lamina berbasis karung plastik bekas (woven bag). Jurnal Teknik Mesin Indonesia, 2018;13(2):44-47.

[18] Mohammed AA, Bachtiar D, Siregar JP, Rejab MRM. Effect of sodium hydroxide on the tensile properties of sugar palm fiber reinforced thermoplastic polyurethane composites. Journal of Mechanical Engineering and Sciences. 2016;10(1):1765-77.

[19] Maryanti B, Sonief AA, Wahyudi S. Pengaruh alkalisasi komposit serat kelapapoliester terhadap kekuatan tarik. Jurnal Rekayasa Mesin. 2011;2(2):123-129.

[20] Diharjo K, Elharomy I, Purwanto A. Pengaruh fraksi volume filler terhadap kekuatan bending dan ketangguhan impak komposit nanosilika-phenolic. Rekayasa Mesin. 2014;5(1):27-32.

[21] Oroh J, Sappu FP, Lumintang RC. Analisis sifat mekanik material komposit dari serat sabut kelapa. Jurnal Online Poros Teknik Mesin Unsrat. 2013;1(1):1-10. 